\title{
Onkogenesis, Morfologi, dan Modalitas Deteksi Dini Karsinoma Serviks
}

\author{
Elsani P. L. Rapar, ${ }^{1}$ Maria K. Sambuaga, ${ }^{2}$ Meilany F. Durry ${ }^{2}$
}

\author{
${ }^{1}$ Program Studi Pendidikan Dokter Fakultas Kedokteran Universitas Sam Ratulangi, Manado, \\ Indonesia \\ ${ }^{2}$ Bagian Patologi Anatomi Fakultas Kedokteran Universitas Sam Ratulangi, Manado, Indonesia \\ Email: lefinasiarapar@gmail.com
}

\begin{abstract}
The incidence and mortality rates of cervical cancer in developing countries are relatively high compared to developed countries. The main risk factor for cervical cancer is high risk human papilloma virus (HPV) infection, such as types 16 and 18. Types of highrisk HPV expresses oncoproteins E6 and E7 which play an essential role in the pathogenesis of cervical carcinoma through inhibition of the activity of gene group expression products that play a role in suppressing tumor growth, such as $\mathrm{p} 53$ and pRB. This process will cause morphological changes in the squamous epithelium from precancerous lesions to cancer. The development of squamous epithelial cell cancer can be prevented through screening tests in order to detect cervical cancer early. This study was aimed to obtain the oncogenesis, morphology, and early detection modality of cervical carcinoma. This was a literature review study using three databases, as follows: ClinicalKey, PubMed, and Google Scholar. The results explained that p53 and pRB suppression by high-risk HPV oncoproteins E6 and E7 played an important role in the pathogenesis of cervical carcinoma. The most common histological type is squamous cell carcinoma. Screening tests such as visual inspection with acetic acid (VIA), Pap smears and HPV DNA have an important role as modalities for early detection of malignancy. More specifically VIA and Pap smears are suitable for Indonesia which is a developing country, especially when implemented in peripheral areas.
\end{abstract}

Keywords: oncogenesis; morphological changes; early detection; cervical carcinoma

\begin{abstract}
Abstrak: Insidens dan mortalitas kanker serviks di negara berkembang relatif tinggi dibandingkan negara maju. Faktor risiko utama dari kanker serviks adalah infeksi human papilloma virus (HPV) risiko tinggi yaitu tipe 16 dan 18. HPV tipe risiko tinggi mengekspresikan onkoprotein E6 dan E7, yang berperan penting dalam patogenesis karsinoma serviks melalui inhibisi terhadap aktivitas produk-produk ekspresi kelompok gen yang berperan dalam menekan pertumbuhan tumor, seperti p53 dan pRB. Proses ini akan menyebabkan perubahan morfologik pada epitel skuamosa mulai dari lesi prakanker sampai kanker. Perkembangan kanker sel epitel skuamosa dapat dicegah melalui pemeriksaan skrining guna mendeteksi dini kanker serviks. Penelitian ini bertujuan untuk mengetahui onkogenesis, morfologi, dan modalitas deteksi dini karsinoma serviks. Jenis penelitian ialah literature review menggunakan tiga basis data yaitu ClinicalKey, PubMed, dan Google Scholar. Hasil penelitian mendapatkan bahwa penekanan p53 dan pRB oleh onkoprotein HPV risiko tinggi E6 dan E7 sangat berperan penting dalam patogenesis karsinoma serviks. Tipe histologik tersering ialah tipe karsinoma sel skuamosa. Pemeriksaan skrining seperti pemeriksaan inspeksi visual dengan asam asetat (IVA), Pap smear dan HPV DNA memiliki peran penting sebagai modalitas deteksi dini keganasan. Lebih khusus IVA dan Pap smear cocok untuk negara Indonesia yang merupakan negara berkembang, terutama bila diimplementasikan di daerah perifer.
\end{abstract}

Kata kunci: onkogenesis; perubahan morfologik; deteksi dini; karsinoma serviks 


\section{PENDAHULUAN}

Karsinoma serviks adalah keganasan di daerah serviks, umumnya memiliki gejala perdarahan per vaginam yang abnormal, serta nyeri dan perdarahan saat bersenggama namun pada beberapa kasus mungkin tidak memiliki gejala nyata hingga kanker tersebut memasuki stadium lanjut. ${ }^{1}$

Secara global, berdasarkan data yang diambil dari Global Cancer Incidence, Mortality and Prevalence (GLOBOCAN), International Agency for Research on Cancer (IARC) pada tahun 2018 diperkirakan terdapat 570.000 kasus dan 311.000 kematian kanker serviks. Kanker serviks sering terdiagnosis di 28 negara dan merupakan penyebab utama kematian akibat kanker di 42 negara, yang sebagian besar berada di Afrika Sub-Sahara dan Asia Tenggara. Banyaknya angka kasus terdiagnosis dan kematian akibat kanker serviks ini, relatif 7 hingga 10 kali lebih rendah di Amerika Utara, Australia atau Selandia Baru, dan Asia Barat (Arab Saudi dan Irak). ${ }^{2}$

Negara maju memiliki insidens dan mortalitas yang relatif rendah karena banyak wanita dengan teratur memeriksakan diri lewat pemeriksaan Pap smear yang mendeteksi dini lesi pra kanker sehingga dapat diterapi dengan segera dan mencegah berubah menjadi kanker. ${ }^{3}$ Negara berkembang memiliki insidens dan mortalitas relatif tinggi disebabkan banyak penderita yang tidak teratur menjalankan pemeriksaan skrining sehingga meningkatkan risiko terjadinya keterlambatan diagnosis. ${ }^{4}$

Salah satu faktor risiko kanker serviks ialah infeksi human papilloma virus (HPV) onkogenik atau HPV risiko tinggi yaitu HPV yang mengekspresikan protein yang sangat berperan dalam patogenesis kanker serviks (onkoprotein). HPV merupakan virus deoxyribo nucleic acid (DNA) yang menginfeksi manusia. Karakteristik onkogenik HPV berasal dari onkoprotein E6 dan E7 yang bertindak menghambat p53 dan penekan tumor pRB. Sekitar 5\% dari semua kanker secara global disebabkan terutama oleh HPV yang dikenal sebagai HPV risiko tinggi, termasuk HPV tipe 16, 18, 31, 33, 35, $39,45,51,52,56,58$, dan $59.5,6$
Infeksi HPV sering terjadi setelah memulai aktifitas seksual terutama bagi seseorang yang memiliki banyak pasangan dalam beraktifitas seksual. Sebagian besar infeksi HPV tidak menunjukkan gejala atau penyakit dan sembuh dalam 12-24 bulan setelah infeksi. Hanya sebagian kecil dari infeksi yang berkembang menjadi lesi preneoplastik yang menyebabkan kanker. Infeksi HPV yang menetap diperlukan untuk memulai proses onkogenik. Dalam hal ini, viral load dan tipe virus merupakan kofaktor utama untuk perkembangan infeksi menjadi lesi intraepitel serviks dan kanker. ${ }^{6}$

Pendekatan yang komprehensif mengenai hal yang berkaitan dengan kanker serviks diperlukan agar dampak kesehatan yang merugikan dari infeksi HPV dapat dicegah, disaring, dan diobati, sehingga angka kejadian kanker serviks dapat ditekan sebagai masalah kesehatan masyarakat. ${ }^{6,7}$ Berdasarkan latar belakang yang telah diuraikan, penulis tertarik untuk menelaah berbagai informasi ilmiah mengenai onkogenesis, morfologi, dan modalitas deteksi dini pada karsinoma serviks.

\section{METODE PENELITIAN}

Penelitian ini merupakan literature review. Pencarian data dibatasi pada lima tahun terakhir dengan menggunakan ClinicalKey, PubMed, dan Google Scholar. Pengambilan data sekunder diperoleh dari hasil penelitian terdahulu yang berkaitan dengan topik dan sesuai dengan kriteria inklusi dan eksklusi yang dianalisis.

\section{HASIL PENELITIAN}

Setelah melalui tahap seleksi studi didapatkan 24 literatur. Terdapat berbagai literatur yang menguraikan beragam bahasan yang dipakai sebagai tinjauan onkogenesis (Tabel 1), morfologi (Tabel 2), dan modalitas deteksi dini pada karsinoma serviks (Tabel 3). Selain itu terdapat literatur penelitian yang menyajikan persentase tipe histologik (Tabel 4), persentase sensitivitas dan spesifisitas dari pemeriksaan skrining (Tabel 5) yang dipakai dalam penelitian ini, serta kelebihan dan kekurangan masingmasing pemeriksaan skrining (Tabel 6). 
Tabel 1. Daftar literatur yang digunakan dalam pembahasan onkogenesis karsinoma serviks

\begin{tabular}{|c|c|c|c|}
\hline $\begin{array}{l}\text { Peneliti/Tahun/ } \\
\text { Lokasi penelitian }\end{array}$ & Judul Jurnal & $\begin{array}{c}\text { Desain } \\
\text { Penelitian } \\
\end{array}$ & Onkogenesis \\
\hline $\begin{array}{llll}\text { Small } & \text { W et al/ } \\
2017^{8} & & \end{array}$ & $\begin{array}{l}\text { Cervical cancer: } a \\
\text { global health crisis }\end{array}$ & Review & $\begin{array}{l}\text { Serviks dilapisi epitel skuamosa bertingkat } \\
\text { pada ektoserviks dan epitel torak pada } \\
\text { endoserviks, transisi antara dua epitel ini } \\
\text { disebut squamocolumnar junction (SCJ) yang } \\
\text { diyakini miliki risiko terbesar terhadap } \\
\text { transformasi neoplastic }\end{array}$ \\
\hline $\begin{array}{l}\text { Claritha DC et al/ } \\
\text { 2020/Indonesia }{ }^{9}\end{array}$ & $\begin{array}{l}\text { Hubungan antara lesi } \\
\text { prakanker serviks de- } \\
\text { ngan sosiodemografi } \\
\text { perempuan di Kecamat- } \\
\text { an Legok Kabupaten } \\
\text { Tangerang tahun } 2018\end{array}$ & $\begin{array}{l}\text { Studi } \\
\text { analitik } \\
\text { dengan } \\
\text { pendekatan } \\
\text { cross } \\
\text { sectionaI }\end{array}$ & $\begin{array}{l}\text { Metaplasia skuamosa sangat meningkat pada } \\
\text { periode dewasa muda sehingga berisiko terjadi } \\
\text { transformasi atipik skuamosa yang dapat } \\
\text { berkembang menjadi neoplasia intraepitel } \\
\text { serviks }\end{array}$ \\
\hline $\begin{array}{l}\text { Balasubramaniam } \\
\text { SD et al/2019/ } \\
\text { Malaysia }^{10}\end{array}$ & $\begin{array}{l}\text { Key molecular events in } \\
\text { cervical cancer deve- } \\
\text { lopment }\end{array}$ & Review & $\begin{array}{l}\text { Onkoprotein HPV, E6 dan E7, menginaktivasi } \\
\text { p53 dan pRB yang sangat penting peker- } \\
\text { jaannya dalam menekan pertumbuhan tumor. }\end{array}$ \\
\hline $\begin{array}{l}\text { Pruski D et al/ } \\
\text { 2019/Poland }{ }^{11}\end{array}$ & $\begin{array}{l}\text { Sensitivity and specifi- } \\
\text { city of } H R H P V \text { E6/E7 } \\
m R N A \text { test in detecting } \\
\text { cervical squamous } \\
\text { intraepithelial lesion } \\
\text { and cervical cancer }\end{array}$ & & $\begin{array}{l}\text { Fungsi p53 sebagai dasar dalam kontrol } \\
\text { pergerakan siklus sel dari G1 ke S. }\end{array}$ \\
\hline $\begin{array}{l}\text { Stiasny A et al/ } \\
\text { 2016/Jerman }\end{array}$ & $\begin{array}{l}\text { Immunohistochemical } \\
\text { evaluation of E6/E7 } \\
\text { HPV oncoproteins } \\
\text { staining in cervical } \\
\text { cancer }\end{array}$ & & $\begin{array}{l}\text { Onkoprotein E7 dari HPV menginaktivasi pRB } \\
\text { dengan memfosforilasi agar E2F bebas dan } \\
\text { menginduksi transkripsi gen }\end{array}$ \\
\hline $\begin{array}{l}\text { Savira } M / 2018 / \\
\text { Indonesia }^{13}\end{array}$ & $\begin{array}{l}\text { Biologi molekuler } \\
\text { human papilloma virus }\end{array}$ & Review & $\begin{array}{l}\text { E2F teraktivasi setelah } \mathrm{E} 7 \text { hambat } \mathrm{pRB} \text {, dan } \\
\text { membuat siklus sel masuk ke fase } \mathrm{S} \text { sehingga } \\
\text { terjadi replikasi virus. }\end{array}$ \\
\hline
\end{tabular}

Tabel 2. Daftar literatur yang digunakan dalam bahasan morfologi karsinoma serviks

\begin{tabular}{|c|c|c|c|}
\hline $\begin{array}{c}\text { Peneliti/Tahun/ } \\
\text { Lokasi penelitian }\end{array}$ & Judul Jurnal & $\begin{array}{c}\text { Desain } \\
\text { Penelitian }\end{array}$ & Morfologi \\
\hline $\begin{array}{l}\text { Permana PH et al/ } \\
\text { 2017/Indonesia }\end{array}$ & $\begin{array}{l}\text { Karakteristik karsinoma } \\
\text { serviks di RS Dr. M. } \\
\text { Djamil Padang }\end{array}$ & $\begin{array}{l}\text { Deskriptif } \\
\text { retrospektif }\end{array}$ & $\begin{array}{l}\text { Tipe histologik karsinoma serviks ter- } \\
\text { banyak ialah tipe sel skuamosa diikuti } \\
\text { oleh adenokarsinoma dan tipe histologik } \\
\text { lainnya }\end{array}$ \\
\hline $\begin{array}{l}\text { Herlana F et al/ } \\
\text { 2017/Indonesia }\end{array}$ & $\begin{array}{l}\text { Karakteristik pasien kan- } \\
\text { ker serviks berdasar atas } \\
\text { usia, paritas, dan gambar- } \\
\text { an histopatologi di RSUD } \\
\text { Al-Ihsan Bandung }\end{array}$ & $\begin{array}{l}\text { Deskriptif } \\
\text { observasional } \\
\text { dengan } \\
\text { pendekatan } \\
\text { cross sectional }\end{array}$ & $\begin{array}{l}\text { Tipe histologik karsinoma serviks ter- } \\
\text { banyak ialah tipe sel skuamosa diikuti } \\
\text { oleh adenokarsinoma dan tipe histologik } \\
\text { lainnya }\end{array}$ \\
\hline $\begin{array}{l}\text { Rozario S do et al/ } \\
\text { 2019/Brasil }\end{array}$ & $\begin{array}{l}\text { Characterization of wo- } \\
\text { men with cervical cancer } \\
\text { assisted at Inca by histo- } \\
\text { logical type }\end{array}$ & $\begin{array}{l}\text { Observasional } \\
\text { retrospektif } \\
\text { dengan } \\
\text { pendekatan } \\
\text { kohort }\end{array}$ & $\begin{array}{l}\text { Tipe histologik karsinoma serviks ter- } \\
\text { banyak ialah tipe sel skuamosa diikuti } \\
\text { oleh adenokarsinoma dan tipe histologik } \\
\text { lainnya }\end{array}$ \\
\hline
\end{tabular}


Oktaviani BD et Karakteristik klinikopatoal/2018/Indonesia ${ }^{17}$ logi penderita kanker serviks uteri berdasarkan data di Laboratorium Patologi Anatomi RSUP Sang-lah Denpasar tahun 2011-2015

Nowakowski A et Cervical cancer histoal/2016/Poland ${ }^{18}$

logy, staging and survival before and after implementation of organized cervical screening programme in Poland

Latifah SRN/2017/ Hubungan stadium kli-nis Indonesia $^{19}$ dengan derajat diferensiasi sel pada pasien karsinoma sel skuamosa serviks uteri di RSUD Abdul Moeloek Bandar Lampung
Deskriptif retrospektif

Analisis cross sectional retrospektif

Analisis crosssectional
Tipe histologik karsinoma serviks terbanyak ialah tipe sel skuamosa diikuti oleh adenokarsinoma dan tipe histologik lainnya

Tipe histologik karsinoma serviks terbanyak ialah tipe sel skuamosa diikuti oleh adenokarsinoma dan tipe histologik lainnya

Penggolongan derajat diferensiasi karsinoma sel skuamosa yang terbagi atas keratinisasi dan non-keratinisasi

Tabel 3. Daftar literatur yang digunakan dalam bahasan modalitas deteksi dini karsinoma serviks

\begin{tabular}{|c|c|c|c|}
\hline $\begin{array}{l}\text { Peneliti/Tahun/ } \\
\text { Lokasi penelitian }\end{array}$ & Judul Jurnal & $\begin{array}{c}\text { Desain } \\
\text { Penelitian }\end{array}$ & Modalitas Deteksi Dini \\
\hline $\begin{array}{l}\text { Romli R et al/ } \\
\text { 2019/Malaysia }\end{array}$ & $\begin{array}{l}\text { Cervical cancer and Pap smear } \\
\text { screening: Knowledge, attitude } \\
\text { and practice among working } \\
\text { women in northern state of } \\
\text { Malaysia. }\end{array}$ & $\begin{array}{l}\text { Analisis } \\
\text { cross- } \\
\text { sectional }\end{array}$ & $\begin{array}{l}\text { Pemeriksaan skrining dilakukan untuk } \\
\text { mendeteksi dini sel-sel yang abnormal dan } \\
\text { mencegah perkembangan sel menjadi } \\
\text { keganasan, diharapkan dapat menurunkan } \\
\text { insidensi dan mortalitas. }\end{array}$ \\
\hline $\begin{array}{l}\text { Juanda D, Kesu- } \\
\text { ma H/2015/Indo- } \\
\text { nesia }^{21}\end{array}$ & $\begin{array}{l}\text { Pemeriksaan metode IVA (In- } \\
\text { speksi Visual Asam Asetat) un- } \\
\text { tuk pencegahan kanker serviks }\end{array}$ & & $\begin{array}{l}\text { Pelaksanaan deteksi dini di Indonesia } \\
\text { masih rendah, sedangkan jika skrining } \\
\text { dilakukan secara efektif dapat menurunkan } \\
\text { angka insidens dan mortalitas }\end{array}$ \\
\hline $\begin{array}{l}\text { Domgue JF et al/ } \\
\text { 2019/Houston }{ }^{22}\end{array}$ & $\begin{array}{l}\text { Prevalence and determinants of } \\
\text { cervical cancer screening with a } \\
\text { combination of cytology and } \\
\text { human papillomavirus testing }\end{array}$ & $\begin{array}{l}\text { Studi } \\
\text { survei }\end{array}$ & $\begin{array}{l}\text { Skrining sitologi mengacu pada pemerik- } \\
\text { saan morfologik sel-sel dari mukosa serviks } \\
\text { yang diperoleh melalui Pap smear }\end{array}$ \\
\hline $\begin{array}{l}\text { Mittal S et al/ } \\
2020^{23}\end{array}$ & $\begin{array}{l}\text { Atlas of visual inspection of the } \\
\text { cervix with acetic acid for } \\
\text { screening, triage, and assess- } \\
\text { ment for treatment: IARC } \\
\text { Cancer Base No. } 16\end{array}$ & & $\begin{array}{l}\text { Prosedur pemeriksaan inspeksi visual } \\
\text { dengan asam asetat (IVA) yang dapat } \\
\text { mendeteksi dini lesi prekursor kanker } \\
\text { serviks dengan lakukan inspeksi visual } \\
\text { setelah aplikasi asam asetat pada wanita } \\
\text { yang tampak normal dan asimtomatik, di } \\
\text { mana akan terlihat gambaran plak putih } \\
\text { pada lokasi tempat diberikan asam asetat } \\
\text { yang berarti epitel serviks tersebut } \\
\text { memiliki sel yang abnormal. }\end{array}$ \\
\hline $\begin{array}{l}\text { Vahedpoor } Z \text { et } \\
\text { al/2019/Iran }\end{array}$ & $\begin{array}{l}\text { Comparison of the diagnostic } \\
\text { value of the visual inspection } \\
\text { with acetic acid (VIA) and Pap } \\
\text { smear in cervical cancer } \\
\text { screening }\end{array}$ & $\begin{array}{l}\text { Cross- } \\
\text { sectional }\end{array}$ & $\begin{array}{l}\text { Jumlah sampel ada } 440 \text { dan semua wanita } \\
\text { menjalani tes Hasil penelitiannya, sensiti- } \\
\text { vitas dan spesifisitas Pap smear } 29,7 \% \text { dan } \\
85,5 \% \text { dan untuk IVA } 94,6 \% \text { dan } 81,6 \%\end{array}$ \\
\hline $\begin{array}{l}\text { Indarti J et al/ } \\
\text { 2017/Indonesia } \\
25\end{array}$ & $\begin{array}{l}\text { The accuration of liquid based } \\
\text { cytology and HPV DNA Test } \\
\text { combination as precervical } \\
\text { cancer lesion screening }\end{array}$ & $\begin{array}{l}\text { Cross- } \\
\text { sectional }\end{array}$ & $\begin{array}{l}\text { Jumlah sampel ada } 138 \text {, didapatkan hasil } \\
\text { sensitivitas dan spesifisitas pemeriksaan } \\
\text { HPV DNA adalah } 81,25 \% \text { dan } 78,57 \% \text {. }\end{array}$ \\
\hline $\begin{array}{l}\text { Shrivastava SK et } \\
\text { al/2018/India }{ }^{26}\end{array}$ & $\begin{array}{l}\text { Cancer cervix: establishing an } \\
\text { evidence-based strategy, an }\end{array}$ & & $\begin{array}{l}\text { Shrivastava et al mendiskusikan hasil } \\
\text { penelitian yang dilakukan Deodhar et al }\end{array}$ \\
\hline
\end{tabular}


experience of a tertiary care

centre in India et $\mathrm{al} / 2015 /$ India $^{27}$ 2015/Indonesia ${ }^{29}$

Rad FS et al/2020/ $\operatorname{Iran}^{30}$

Hapsari $\mathrm{Y}$ et al/ 2019/Indonesia ${ }^{31}$
Bhattacharyya AK

Mastutik $\mathrm{G}$ et al/

Comparative study between Pap smear and visual inspection with acetic acid (VIA) in screening of CIN and early cervical cancer

Huy NVQ et al/ The value of visual inspection 2018/Vietnam ${ }^{28}$ with acetic acid and Pap smear in cervical cancer screening program in low resource settings - a population-based study

Skrining kanker serviks dengan pemeriksaan Pap smear di Puskesmas Tanah Kali Kedinding Surabaya dan Rumah Sakit Mawadah Mojokerto
Cross-

sectional

Cross-

sectional (2012), 5519 wanita dalam rentang usia 3049 tahun, didapatkan nilai sensitivitas dan spesifisitas pemeriksaan IVA $64,5 \%$ dan $84,2 \%$

Penelitian dilakukan pada 300 wanita dengan rentang usia 18-60 tahun didapatkan nilai sensitivitas dan spesifisitas IVA $89 \%$ dan $87 \%$, serta nilai sensitivitas dan spesifisitas Pap smear 52\% dan $95 \%$

Penelitian dilakukan pada tahun 2012-2013 didapat nilai sensitivitas dan spesifisitas IVA $88,8 \%$ dan $43,8 \%$ serta nilai sensitivitas dan spesifisitas Pap smear 58\% dan $85,2 \%$. Pada penelitian ini didiskusikan studi Costa et al (2007) dimana kombinasi Pap smear dan tes HPV memberikan manfaat yang jelas dibandingkan pemeriksaan sitologi tunggal.

Pada penelitiannya, Mastutik et al mendiskusikan dua penelitian dari Saleh HS (2014) yang mendapatkan nilai sensitivitas dan spesifisitas Pap smear 50,1\% dan 93,1\% juga nilai sensitivitas dan spesifisitas IVA $90 \%$ dan $37 \%$. Penelitian lainnya dari Consul et al (2012) mendapatkan nilai sensitivitas dan spesifisitas Pap smear $84,2 \%$ dan $62,1 \%$, serta nilai sensitivitas dan spesifisitas IVA $84,2 \%$ dan 55,2\%

Studi pada 1000 wanita dengan hasil Pap smear abnormal tahun 2007-2018 didapatkan nilai sensitivitas dan spesifisitas $43 \%$ dan $65,9 \%$. Dalam penelitian ini juga didiskusikan studi dari Karimi Zarchi et al (2013) dengan nilai sensitivitas Pap smear $18,2 \%$ dan spesifisitas $98,5 \%$

Cross- IVA memiliki angka positif palsu cukup sectional tinggi menjadi salah satu kekurangan IVA.

DNA HPV dan pemeriksaan Pap smear banyak direkomendasi pada banyak penelitian, namun biaya yang diperlukan masih relatif mahal

Tabel 4. Penelitian yang memiliki persentase jenis morfologik karsinoma serviks

\begin{tabular}{|c|c|c|c|}
\hline $\begin{array}{c}\text { Peneliti/Tahun/ } \\
\text { Lokasi penelitian }\end{array}$ & Metode & Jumlah sampel & Tipe Histologik \\
\hline $\begin{array}{l}\text { Permana PH et al/2010-2013 } \\
\text { (2017 tahun publikasi)/RS Dr. M. } \\
\text { Djamil Padang }\end{array}$ & $\begin{array}{l}\text { Deskriptif } \\
\text { retrospektif }\end{array}$ & $\begin{array}{l}152 \text { kasus: } 84 \\
\text { ada data jenis } \\
\text { histopatologi, } 68 \\
\text { kasus tidak ada } \\
\text { data jenis histo- } \\
\text { patologi }\end{array}$ & $\begin{array}{l}63 \text { kasus karsinoma sel skua- } \\
\text { mosa }(85 \%), 21 \text { kasus adeno- } \\
\text { karsinoma }(15 \%)\end{array}$ \\
\hline $\begin{array}{l}\text { Herlana F et al/Januari 2015-Juni } \\
\text { 2017/RSUD Al-Ihsan Bandung }{ }^{15}\end{array}$ & \begin{tabular}{l}
\multicolumn{2}{l}{ Observasional } \\
deskriptif dengan \\
pendekatan cross \\
sectional
\end{tabular} & 82 kasus & $\begin{array}{l}58 \text { kasus karsinoma sel skua- } \\
\text { mosa }(70,7 \%), 24 \text { kasus adeno- } \\
\text { karsinoma }(29,3 \%)\end{array}$ \\
\hline $\begin{array}{l}\text { Rozario } S \text { do et al/2012-2014 } \\
\text { (tahun publikasi } 2019 \text { )/Brazil } \\
\text { (RS Inca) }^{16}\end{array}$ & $\begin{array}{l}\text { Observasional retro- } \\
\text { spektif dengan pen- } \\
\text { dekatan kohort }\end{array}$ & 1004 kasus & $\begin{array}{l}83,9 \% \text { kasus karsinoma sel } \\
\text { skuamosa, } 16,1 \% \text { kasus adeno- } \\
\text { karsinoma }\end{array}$ \\
\hline
\end{tabular}




\begin{tabular}{|c|c|c|c|c|}
\hline $\begin{array}{l}\text { Oktaviani BD et al/1 Januari } \\
\text { 2011-31 Desember 2015 (tahun } \\
\text { publikasi 2018)/RSUP Sanglah } \\
\text { Denpasar }^{17}\end{array}$ & $\begin{array}{l}\text { Deskriptif } \\
\text { retrospektif }\end{array}$ & & 574 kasus & $\begin{array}{l}394 \text { kasus karsinoma sel skua- } \\
\text { mosa }(68,6 \%), 95 \text { kasus adeno- } \\
\text { karsinoma (16,6\%), 52 kasus } \\
\text { karsinoma sel adenoskuamosa } \\
(9,1 \%), 33 \text { kasus tipe lain }(5,7 \%)\end{array}$ \\
\hline $\begin{array}{l}\text { Nowakowski A et al/2009-2012 } \\
\text { (tahun publikasi 2016)/Poland }{ }^{18}\end{array}$ & $\begin{array}{l}\text { Analisis } \\
\text { sectional } \\
\text { retrospektif }\end{array}$ & cross- & 165 kasus & $\begin{array}{l}142 \text { kasus karsinoma sel skua- } \\
\text { mosa }(86,1 \%), 18 \text { kasus adeno- } \\
\text { karsinoma }(10,9 \%), 5 \text { tipe } \\
\text { histologik lain }(3 \%)\end{array}$ \\
\hline
\end{tabular}

Tabel 5. Persentase sensitivitas dan spesifisitas pemeriksaan IVA, Pap smear, dan HPV DNA berdasarkan beberapa penelitian

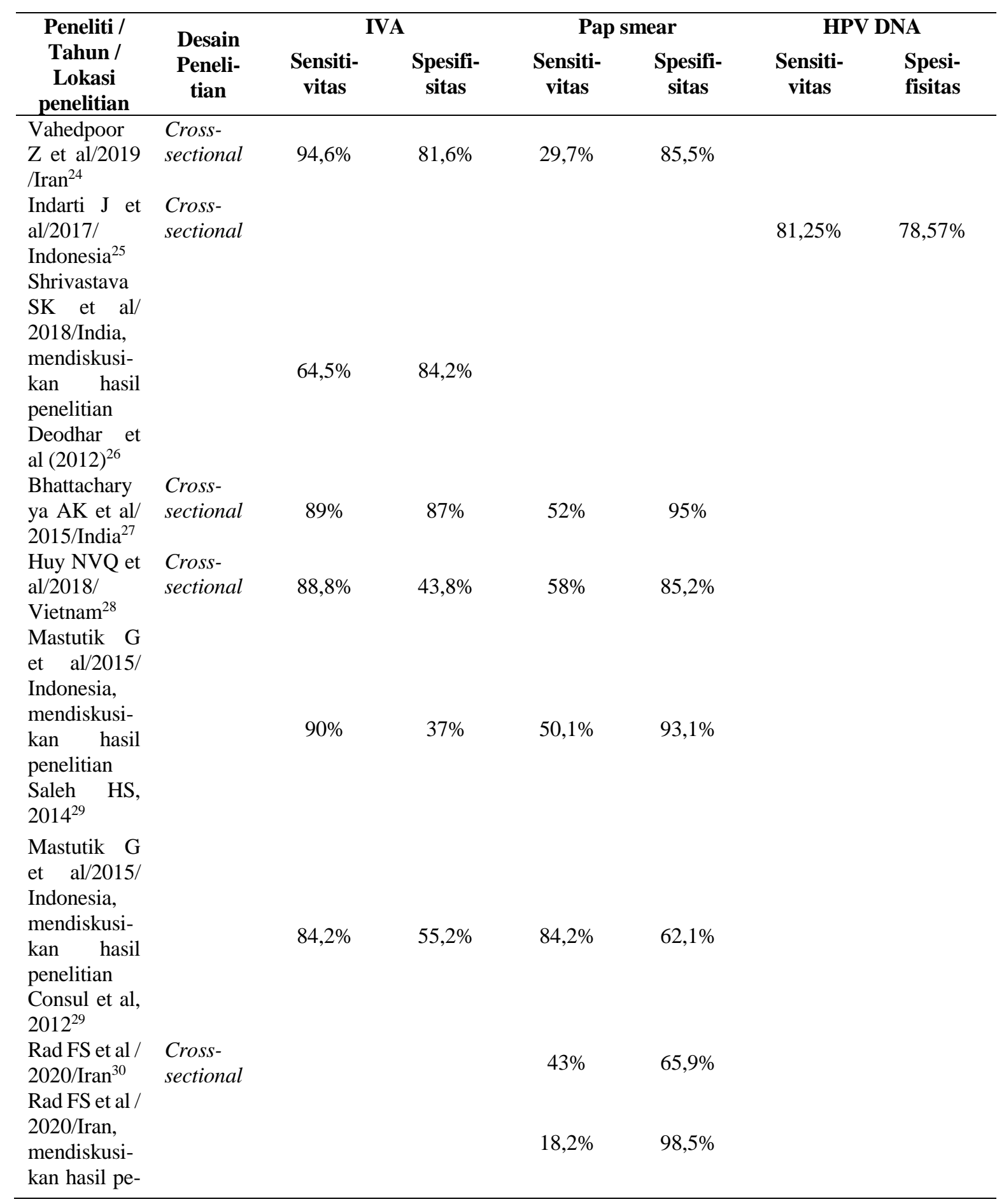


nelitian dari

Karimi

Zarchi et al,

$2013^{30}$

Tabel 6. Pemeriksaan-pemeriksaan skrining, beserta kekurangan dan kelebihannya ${ }^{12}$

\begin{tabular}{|c|c|c|c|}
\hline Metode & Prosedur & Kelebihan & Kekurangan \\
\hline $\begin{array}{l}\text { HPV } \\
\text { DNA }\end{array}$ & $\begin{array}{l}\text { Sel serviks } \\
\text { diambil meng- } \\
\text { gunakan sikat } \\
\text { atau swab oleh } \\
\text { penyedia atau } \\
\text { diri sendiri dan } \\
\text { sampel disim- } \\
\text { pan dalam } \\
\text { wadah dengan } \\
\text { larutan peng- } \\
\text { awet yang } \\
\text { sesuai kemu- } \\
\text { dian dikirim ke } \\
\text { laboratorium. }\end{array}$ & $\begin{array}{l}\text { a. Pengambilan spesimen seder- } \\
\text { hana } \\
\text { b. Pengambilan sampel sendiri } \\
\text { dimungkinkan } \\
\text { c. Sangat sensitif } \\
\text { d. Memungkinkan interval skrining } \\
\text { diperpanjang hingga } 10 \text { tahun } \\
\text { untuk wanita dengan skrining } \\
\text { negatif } \\
\text { e. Mungkin untuk mendapatkan } \\
\text { hasil dalam beberapa jam }\end{array}$ & $\begin{array}{l}\text { a. Membutuhkan peralatan khusus dan } \\
\text { bahan consumable } \\
\text { b. Mahal } \\
\text { c. Memerlukan laboratorium fungsional, } \\
\text { fasilitas penyimpanan untuk sampel } \\
\text { dan bahan consumable } \\
\text { d. Pengaturan transportasi spesimen } \\
\text { mungkin rumit } \\
\text { e. Hasil tidak segera tersedia }\end{array}$ \\
\hline IVA & $\begin{array}{l}\text { Serviks dilihat } \\
\text { dengan mata te- } \\
\text { lanjang di ba- } \\
\text { wah sumber ca- } \\
\text { haya yang baik } \\
\text { sekitar } 1 \text { menit } \\
\text { setelah meng- } \\
\text { gunakan asam } \\
\text { asetat 3-5\% }\end{array}$ & $\begin{array}{l}\text { a. Relatif sederhana dan dapat } \\
\text { dilakukan oleh tenaga kesehatan } \\
\text { terlatih } \\
\text { b. Murah } \\
\text { c. Hasil segera tersedia } \\
\text { d. Hasil positif dapat segera diikuti } \\
\text { dengan pengobatan } \\
\text { e. Bahan yang diperlukan mudah } \\
\text { didapat }\end{array}$ & $\begin{array}{l}\text { a. Tes subyektif, membutuhkan pela- } \\
\text { tihan dan pengawasan yang ketat dari } \\
\text { penyedia untuk memastikan kinerja } \\
\text { yang baik } \\
\text { b. Sensitivitas lebih rendah dari tes HPV } \\
\text { c. Sensitivitas lebih rendah pada wanita } \\
\text { pascamenopause }\end{array}$ \\
\hline $\begin{array}{l}\text { Pap } \\
\text { smear }\end{array}$ & $\begin{array}{l}\text { Penyedia meng- } \\
\text { ambil sel ser- } \\
\text { viks mengguna- } \\
\text { kan sikat dan } \\
\text { spatula dan dile- } \\
\text { takkan pada ob- } \\
\text { jek glass kemu- } \\
\text { dian diwarnai } \\
\text { untuk diperiksa } \\
\text { oleh ahli pato- } \\
\text { logi. }\end{array}$ & $\begin{array}{l}\text { a. Banyak digunakan di negara } \\
\text { dengan sumber daya tinggi } \\
\text { b. Pelatihan dan mekanisme untuk } \\
\text { quality control dan quality } \\
\text { assurance sudah mapan }\end{array}$ & $\begin{array}{l}\text { a. Memerlukan laboratorium fungsional, } \\
\text { fasilitas penyimpanan untuk sampel } \\
\text { dan bahan consumable } \\
\text { b. Pengaturan transportasi spesimen } \\
\text { mungkin rumit } \\
\text { c. Hasil tidak segera tersedia } \\
\text { d. Memerlukan kontrol kualitas yang } \\
\text { ketat di setiap tahapan }\end{array}$ \\
\hline
\end{tabular}

\section{BAHASAN \\ Onkogenesis}

Serviks dilapisi oleh epitel skuamosa bertingkat yang menutupi ektoserviks dan epitel torak/kolumnar yang menyekresi lendir yang merupakan karakteristik kanal endoserviks. Transisi antara dua jenis sel ini disebut squamocolumnar junction (SCJ), dan area inilah yang diyakini memiliki risiko terbesar terjadinya transformasi neoplastik virus. Tumor yang timbul di ektoserviks paling sering ialah karsinoma sel skuamosa (KSS). Jenis KSS merupakan penyebab sekitar $75 \%$ kasus karsinoma serviks invasif. Sebaliknya, tumor yang timbul dari endoserviks lebih mungkin menjadi adenokarsinoma. ${ }^{8}$

Pada penelitian yang dilakukan oleh Claritha DC et $\mathrm{al}^{9}$ yang mendiskusikan penelitian dari Nelli tahun 2017 dan juga penelitian dari Ningsih tahun 2017, disimpulkan bahwa wanita, terutama yang bersenggama usia dini di bawah 20 tahun, di mana pada usia pubertas SCJ menjadi 
terekspos menyebabkan epitel torak terlihat pada ektoserviks dan akhirnya mengalami metaplasia skuamosa (perubahan satu tipe sel dewasa menjadi tipe sel dewasa lain, dalam hal ini epitel berlapis gepeng menjadi selapis torak) membentuk daerah yang disebut zona transformasi dan mengakibatkan seseorang lebih rentan terinfeksi Human Papilloma Virus (HPV) yang dapat berkembang menjadi kanker serviks. ${ }^{9,32,33}$

Tipe HPV dibagi atas risiko tinggi dan risiko rendah. Perbedaannya terletak pada kecenderungan virus dalam proses karsinogenesis. HPV risiko tinggi contohnya tipe $16,18,31,33,35,39,45,51,52,56,58$, dan 59 , merupakan faktor risiko terpenting dari perkembangan lesi pre kanker. ${ }^{6}$ Meskipun terdapat hubungan kuat antara infeksi HPV dengan kanker serviks, HPV saja tidak cukup untuk memulai proses patogenesis. Terdapat beragam faktor lain yang diduga memiliki peranan seperti imunkitas dan hormonal pejamu serta ko-infeksi dengan patogen lain yang menular secara seksual. ${ }^{32}$ Berikut ini dipaparkan infeksi HPV risiko tinggi dan kemungkinan konsekuen-sinya. Deteksi DNA HPV dalam biopsi jaringan dapat mengindikasikan infeksi produktif low-grade squamous intra-epithelial lesion (LSIL) atau high-grade squamous intraepithelial lesion (HSIL), adanya partikel virus di permukaan epitel tanpa infeksi (misalnya dari penularan baru); atau infeksi laten atau infeksi silent. Infeksi memerlukan virus HPV masuk ke dalam sel epitel yang aktif secara mitosis dari lapisan basal, dimana dalam epitel berlapis dianggap membutuhkan lesi mikro. Pada lapisan sel kolumnar, infeksi diperkirakan difasilitasi oleh dekatnya sel target dengan permukaan epitel, yang memungkinkan virus mengakses tipe sel yang tidak dapat mendukung siklus hidup produktif penuh. Setelah infeksi, ekspresi genom virus terkadang dapat dihambat (misalnya dengan metilasi genom), yang mengarah ke infeksi silent. Genom virus berdiam pada inti sel epitel serviks yang terdapat pada lapisan basal tanpa adanya manifestasi jelas. Infeksi dapat menyebabkan pola ekspresi gen virus yang teratur, mengarah ke sintesis virus dan pelepasan virus dari lapisan epitel atas (infeksi produktif atau LSIL), atau ke deregulasi ekspresi gen virus dan neoplasia intraepitelial tingkat tinggi (HSIL). Lesi derajat tinggi yang persisten dihubungkan dengan peningkatan risiko integrasi genom ke dalam kromosom sel inang dan perkembangan menjadi kanker. Pada kebanyakan kasus, infeksi HPV dapat terselesaikan karena respon imun yang dimediasi oleh sel. Hal ini dapat menyebabkan pembersihan virus atau latensi virus dan episome virus yang persisten di lapisan basal epitel tanpa penyelesaian siklus hidup. Pola ekspresi gen virus selama latensi tidak dapat dijelaskan dengan baik. Ekspresi gen deregulasi yang persisten, seperti yang terjadi pada Cervical Intraepithelial Neoplasia (CIN) 3 dan setelah integrasi genom virus, dapat menyebabkan akumulasi perubahan genetik sekunder dalam sel inang yang terinfeksi dan perkembangan kanker. Ini difasilitasi oleh ekspresi berlebihan dari protein E6 dan E7 yang berisiko tinggi. ${ }^{34}$

Human Papilloma Virus (HPV) menginfeksi sel skuamosa imatur (immature squamous cells) pada zona transformasi. Dalam keadaan normal, maturasi sel skuamosa disertai dengan penghentian replikasi DNA agar dapat mencegah produksi virus. Namun, HPV risiko tinggi memiliki jalan agar dapat menangani kendala tersebut dengan kerja dua onkoprotein virus, yakni E6 dan E7 yang akan menghambat p53 dan RB. Adapun p53 dan RB tergolong pada kelompok tumor suppresor gene (TSG) atau gen penekan tumor yang berperan dalam menekan pembelahan sel skuamosa bersamaan dengan maturasi sel..$^{10,32}$

Protein RB berfungsi mengatur pos pengecekan G1/S yang adalah pintu masuk yang harus dilewati sebelum replikasi DNA dimulai. Fase G1 merupakan penentuan apakah sel dapat meneruskan siklus sel atau keluar dari siklus sel dan berdiferensiasi. RB merupakan protein pengikat DNA dan bekerja melalui perubahan status fosforilasi. Sinyal yang merangsang kelanjutan siklus sel menyebabkan RB fosforilasi dan inaktivasi, sedangkan sinyal yang meng- 
hambat siklus sel bekerja dengan menjaga RB dalam keadaan hipofosforilasi aktif. ${ }^{32}$

Replikasi DNA (fase S) memerlukan aktivasi kompleks siklin E-Cyclin Dependent Kinase inhibitor 2 (CDK) dan ekspresi siklin E-CDK 2 tergantung pada faktor transkripsi E2F. Awal G1, RB dalam bentuk hipofosforilasi yang aktif, mengikat dan menghambat E2F, sehingga mencegah transkripsi siklin E, dan replikasi DNA. Untuk menghambat E2F terdapat dua cara, yaitu: Pertama, RB mengasingkan E2F agar tidak berinteraksi dengan aktivator transkripsi lain; Kedua, RB merekrut protein yang mengikat gen yang responsif terhadap E2F yakni siklin yaitu protein histon metiltransferase dan histon deasetilase sehingga tidak peka terhadap faktor transkripsi. ${ }^{32}$

Situasi berubah ketika sinyal faktor pertumbuhan menyebabkan terekspresinya siklin dan mengaktifkan kompleks siklin DCDK4/6. Jika rangsangannya cukup kuat maka akan memfosforilasi RB sehingga menjadi inaktif dan melepaskan E2F yang dapat merangsang gen target seperti siklin E, dan kompleks siklin E-CDK kemudian menyebabkan replikasi DNA. Setelah masuk fase $\mathrm{S}$, sel akan membelah tanpa memerlukan faktor pertumbuhan tambahan. ${ }^{32}$

Pada HPV onkogenik, onkoprotein E7 mengikat bentuk hipofosforilasi dari RB sehingga mencegah RB untuk menghambat E2F dan akibatnya E2F akan menginduksi transkripsi gen yang berperan dalam fase $S$ sehingga replikasi DNA menjadi berlebihan dan tidak stabil. ${ }^{12,13}$

Gen penekan tumor TP53 yang dikenal sebagai guardian of the genome, menyandi atau mengekspresikan protein p53 yang diaktivasi ketika ada stres seperti kerusakan DNA dan membantu pemulihan DNA dengan menghentikan siklus sel pada G1 dan menginduksi ekspresi gen perbaikan DNA. Penghambatan perubahan neoplastik terjadi melalui tiga mekanisme yang berkaitan, yakni aktivasi penghentian sementara siklus sel (quiescence/diam/G1 arrest), induksi penghentian permanen siklus sel (senescence/penuaan), atau induksi apoptosis (kematian sel yang terprogram). Mekanisme yang berperan ialah penghentian sementara siklus oleh p53, penuaan sel/senescence, dan apoptosis. Mengenai penghentian sementara siklus sel oleh p53, pada fase akhir G1 terjadi mekanisme penghentian sementara siklus sel yang disebabkan oleh p21 yang merupakan salah satu CDK Inhibitor (CDKI) yang menghambat kompleks siklin-CDK dan mencegah fosforilasi RB sehingga menghentikan siklus sel pada fase G1. Hal ini bermanfaat memberi kesempatan pada sel untuk memperbaiki kerusakan DNA. Bila kerusakan tidak dapat diperbaiki maka sel akan memasuki siklus penghentian permanen atau penuaan. Penuaan sel/senescence berarti terjadi penghentian siklus secara permanen di mana sel bisa hidup namun tidak bisa membelah (sinyal untuk masuk ke dalam siklus sel terinhibisi). Induksi apoptosis terjadi pada sel yang tidak reversibel (perlindungan akhir terhadap transformasi maligna). ${ }^{32}$

Pada HPV risiko tinggi, onkoprotein E6 akan menginduksi ubikuitinisasi atau mekanisme penghancuran p53, sehingga peran p53 untuk mencegah mutasi maupun pertahanan hidup sel supaya tidak mengalami transformasi maligna tidak berlangsung. Akibatnya, jika terjadi kerusakan DNA maka tidak ada penghentian siklus sel, mekanisme perbaikan DNA, maupun apoptosis. Dengan demikian, sel dengan kerusakan DNA akan tetap survive dan berproliferasi, sehingga menyebabkan transformasi sel ke arah keganasan. ${ }^{32}$

\section{Morfologi}

Sekitar 90\% dari karsinoma merupakan karsinoma serviks dengan tipe histologik sel skuamosa dan sebagian besar tumor lainnya ialah adenokarsinoma atau karsinoma sel basal. ${ }^{32}$ Terdapat beberapa penelitian yang memberikan persentase jenis morfologik kanker serviks (Tabel 4). Setiap hasil penelitian pada Tabel 4 sejalan satu sama lain, dengan tipe histologik tersering yang ditemukan baik di Indonesia maupun di luar Indonesia ialah tipe skuamosa yang diikuti oleh tipe adenokarsinoma dan juga tipe histologik lainnya.

Salah satu agen penyebab karsinoma serviks yang menginfeksi sel skuamosa ialah 
HPV. Onkogenesis HPV dimulai dengan adanya perubahan pre kanker pada epitel yang disebut squamous intraepithelial lesion (SIL) yang terbagi menjadi dua tingkatan, yakni SIL derajat rendah (low-grade squamous intraepithelial lesion-LSIL) atau disebut juga neoplasia intraepitel serviks (NIS 1), dan SIL derajat tinggi (high-grade squamous intraepithelial lesion-HSIL) yang mencakup NIS 2 dan 3. LSIL ditandai dengan perubahan displastik sepertiga bawah epitel skuamosa dan terdapat perubahan koilositosis superfisial. Pada HSIL (CIN II), terdapat pembesaran inti dan hiperkromasia yang meluas sampai dua pertiga epitelium. Pada HSIL (CIN III) terdapat diferensiasi hampir hilang seluruhnya, ukuran dan inti sel yang lebih bervariasi, heterogenitas kromatin, mitosis abnormal, dan perubahan yang terjadi hampir mencakup seluruh ketebalan penuh lapisan epitel skuamosa. 32,35

Karsinoma invasif pada serviks berkembang pada zona transformasi dan pada pemeriksaan mikroskopik terlihat jelas invasi stroma sampai tumor eksofitik. Secara mikroskopik tumor invasif sering terdiri atas kumpulan sel skuamosa yang menghasilkan stroma desmoplastik (pembentukan jaringan ikat berlebih). Penilaian dilakukan berdasarkan derajat diferensiasi skuamosa karsinoma serviks invasif. ${ }^{32}$ Pada keratinizing squamous cell carcinoma (keratinisasi karsinoma sel skuamosa) derajat diferensiasi baik, sel masih menyerupai sel asal namun inti biasanya besar, hiperkromatik, terdapat banyak granul keratin dan jembatan antar sel yang jelas serta mitosis yang relatif sedikit. Non-keratinizing squamous cell carcinoma (nonkeratinisasi karsinoma sel skuamosa) terdiri dari sel-sel skuamosa poligonal dalam sarang-sarang sel tumor yang mungkin memiliki jembatan antar sel, tetapi tidak terdapat granul keratin, inti pleomorfik, dan ditemukan banyak mitosis serta mitosis abnormal. ${ }^{19,34}$

\section{Modalitas Deteksi Dini}

Karsinoma serviks invasif sering ditemukan pada wanita yang tidak pernah melakukan pemeriksaan skrining dalam jangka waktu lama. Pada kasus seperti ini, kebanyakan asimtomatik; hal ini dikarenakan pada stadium awal atau pra kanker, kanker serviks belum menunjukkan gejala atau tanda-tanda yang jelas dan tidak diketahui jika proses maligna sudah berlangsung sehingga terlambat memeriksakan diri (keterlambatan diagnosis) dan ketika memeriksakan diri dengan keluhan perdarahan vagina tiba-tiba dan nyeri saat bersenggama, kanker serviks yang ada sudah memasuki stadium lanjut.

Pemeriksaan skrining yang menjadi fokus pada literature review ini ialah pemeriksaan Pap smear, pemeriksaan inspeksi visual dengan asam asetat (IVA), dan HPV DNA yang dapat mendeteksi dini kelainan pada serviks yang memiliki kemungkinan berkembang menjadi kanker. ${ }^{32}$

Lesi prakanker pada serviks dapat dideteksi abnormalitas sel yang ada melalui preparat sitologi jauh sebelum semuanya dapat terlihat secara makroskopis. Deteksi dini SIL merupakan tujuan dilakukannya pemeriksaan Pap smear, dengan mengeksfoliasi sel dari zona transformasi yang kemudian diperiksa menggunakan mikroskop untuk dinilai lebih lanjut. ${ }^{22,32}$

Pap smear sendiri telah menjadi pemeriksaan skrining kanker paling sukses yang pernah dikembangkan. Di Amerika Serikat, skrining menggunakan Pap smear secara drastis telah menurunkan angka insidens serta mortalitas kanker serviks sehingga tidak termasuk 10 besar penyebab kematian akibat kanker di Amerika Serikat. ${ }^{32}$

Inspeksi visual setelah penggunaan asam asetat (IVA) merupakan tes skrining yang bertujuan untuk mendeteksi lesi prekursor kanker serviks dan kanker serviks dini yang melibatkan pemeriksaan serviks uterus di inspeksi secara langsung dengan penerangan yang sesuai setelah aplikasi asam asetat 3-5\%. Interpretasi tes ini didasarkan pada deteksi area acetowhite padat yang berbatas jelas di zona transformasi serviks 1 menit setelah aplikasi asam asetat. ${ }^{23}$ Epitel serviks yang normal transparan akan tampak merah muda karena 
pantulan cahaya dari stroma di bawahnya yang kaya akan pembuluh darah. Terdapat sangat sedikit protein seluler di lapisan superfisial epitel skuamosa dewasa normal. Dengan demikian, hanya sedikit protein yang menggumpal ketika asam asetat dioleskan ke epitel normal dan warna merah muda normal dari epitel skuamosa matang tetap tidak berubah. Epitel serviks dengan NIS tingkat tinggi atau kanker invasif mengandung sel-sel dengan inti besar dan protein inti yang berlimpah sehingga saat diberi asam asetat terjadi dehidrasi seluler dan koagulasi protein seluler yang menyebabkan epitel tampak putih karena cahaya tidak dapat melewati lapisan protein yang terkoagulasi. Sebagian besar sel dalam lesi NIS 1 ialah normal sehingga epitel tampak tipis acetowhite. sedangkan kanker invasif memiliki jumlah protein seluler dan sel abnormal yang tinggi sehingga setelah penggunaan asam asetat akan terlihat gambaran plak putih kapur yang padat. ${ }^{23}$

Selain Pap smear dan IVA, terdapat juga pemeriksaan skrining lainnya yaitu HPV DNA untuk mencari jenis HPV risiko tinggi yang dapat menyebabkan pra kanker dan kanker serviks. ${ }^{36}$ Pemeriksaan HPV DNA sangat sensitif namun spesifisitasnya rendah bila dibandingkan pemeriksaan Pap smear. ${ }^{32}$ Persentase dari nilai-nilai sensitivitas serta spesifisitas dari pemeriksaan IVA, Pap smear, dan HPV DNA berdasarkan beberapa penelitian ditampilkan pada Tabel 5. Bila dibandingkan hasil penelitianpenelitian tersebut, persentase nilai sensitivitas pemeriksaan IVA pada banyak penelitian lebih tinggi daripada pemeriksaan Pap smear. Sebaliknya, persentase nilai spesifisitas pemeriksaan Pap smear pada kebanyakan penelitian lebih tinggi daripada pemeriksaan IVA. ${ }^{24}$

IVA merupakan salah satu metode penapisan yang mudah dan memiliki sensitivitas yang baik namun angka positif palsunya cukup tinggi. Upaya yang dapat dilakukan untuk menurunkan angka kejadian positif palsu ialah melakukan penapisan dengan dua tahap secara serial. Salah satu metode pemeriksaan lainnya yang sudah direkomendasikan pada banyak penelitian sebagai skrining ialah Pap smear dan tes DNA HPV. Tes DNA HPV dianjurkan sebagai prosedur lanjutan pada kasus dengan hasil Pap smear borderline atau abnormal yang dapat membedakan tipe high-risk (onkogenik) dan low-risk (nononkogenik) sehingga dapat segera dilakukan tatalaksana dengan tepat. Pemeriksaan HPV DNA memiliki sensitivitas dan spesifisitas yang lebih tinggi dalam menentukan tipe HPV risiko tinggi dibandingkan dengan IVA dan Pap smear, namun biaya pemeriksaan masih relatif mahal sehingga diperlukan suatu prioritas bagi pasien yang akan diperiksa berupa identifikasi faktor-faktor risiko yang berhubungan dengan insidensi HPV risiko tinggi. ${ }^{31}$ Huy et $\mathrm{al}^{28}$ mendiskusikan penelitian yang dilakukan Costa et al pada tahun 2007 dan mengemukakan bahwa kombinasi pemeriksaan Pap smear dan HPV memberikan keuntungan yang jelas dibanding dengan pemeriksaan sitologi tunggal. Pada kunjungan follow up pertama didapatkan sensitivitas $90 \%$, spesifisitas $50 \%$, nilai prediksi positif $52,9 \%$, dan nilai prediksi negatif $88,9 \%$, sedangkan pada kunjungan follow up kedua didapatkan meningkatnya nilai sensitivitas $100 \%$ dan nilai prediksi negatif $100 \%{ }^{28}$ Gabungan dari kedua pemeriksaan ini memiliki sensitivitas dan nilai prediksi negatif yang tinggi sehingga dapat mendeteksi lebih baik lesi pra kanker. Adapun kelebihan dan kekurangan masing-masing pemeriksaan skrining disajikan pada Tabel $6 .^{33}$

Pemeriksaan IVA dan Pap smear merupakan pemeriksaan yang baik bila disesuaikan dengan kondisi di Indonesia khususnya di daerah perifer dikarenakan pemeriksaannya yang dinilai mudah, murah, cukup efektif, serta efisien. ${ }^{20,21}$ Saat ini skrining deteksi dini kanker serviks di Indonesia melalui pemeriksaan Pap smear dan IVA masih rendah, sedangkan bila skrining dilakukan secara efektif dapat menurunkan insidens dan mortalitas akibat kanker serviks. $^{21}$

\section{SIMPULAN}

Faktor risiko tersering penyebab karsinoma serviks ialah HPV risiko tinggi. HPV 
risiko tinggi mengekspresikan onkoprotein E6 dan E7 yang menginaktivasi penekan tumor p53 dan pRB mengakibatkan sel abnormal akan terus berproliferasi yang berujung pada keganasan sel.

Tipe histologik karsinoma serviks yang paling sering ditemukan ialah tipe karsinoma sel skuamosa diikuti oleh adenokarsinoma.

Pemeriksaan skrining yang dapat dipakai untuk mendeteksi dini lesi prakanker serviks ialah pemeriksaan IVA, Pap smear, dan HPV DNA. Kombinasi ketiganya memiliki sensitivitas dan nilai prediksi negatif yang tinggi sehingga dapat mendeteksi lesi pra kanker lebih baik. Pemeriksaan IVA dan Pap smear merupakan pemeriksaan yang baik bila disesuaikan dengan kondisi di Indonesia karena dinilai mudah, murah, cukup efektif serta efisien dalam mendeteksi dini lesi pre kanker.

\section{Konflik Kepentingan}

Penulis menyatakan tidak terdapat konflik kepentingan dalam studi ini.

\section{DAFTAR PUSTAKA}

1. Tadjoedin H, Agustini S. Buku Ajar Ilmu Penyakit Dalam Jilid III (6th ed). Imu Penyakit Dalam. Jakarta: Interna Publishing, 2014; p. 3054-62.

2. Bray F, Ferlay J, Soerjomataram I, Siegel RL, Torre LA, Jemal A. Global cancer statistics 2018: GLOBOCAN estimates of incidence and mortality worldwide for 36 cancers in 185 countries. CA Cancer J Clin. 2018;68(6):394-424.

3. Centers for Disease Control and Prevention. Cervical cancer statistics. 2020; Available from: https://www.cdc.gov/ cancer/cervical/statistics/index.htm

4. Hidayat E, Sari DH, Fitriyati Y. Hubungan kejadian kanker serviks dengan jumlah paritas di RSUD Dr. Moewardi tahun 2013. J Kedokt dan Kesehat Indones. 2014;6(3):128-36.

5. Nurwijaya H, Andrijono, Suheimi. Cegah dan Deteksi Kanker Serviks [Internet]. Jakarta: PT Elex Media Komputindo; 2010; p. 27-30. Available from: https://books.google.co.id/books?hl=id $\& \mathrm{l}=\& \mathrm{id}=4 \mathrm{kdbDwAAQBAJ} \& \mathrm{oi}=\mathrm{fnd} \&$ pg=PP1\&dq=penyebab+kanker+servik s\&ots $=2 \mathrm{H} 2$ whwsHY7\&sig=RIMkEV7 UgJC2Fa_xP8n4n0Vyne0\&redir_esc $=$ $\mathrm{y} \# \mathrm{v}=$ onepage $\& \mathrm{q}=$ penyebab\&f$=$ false

6. Sanjosé S de, Brotons M, Pavón MA. The natural history of human papillomavirus infection. Best Pract Res Clin Obstet Gynaecol. 2018;47:2-13. Available from: https://www.sciencedirect.com/ science/article/abs/pii/S1521693417301 335

7. World Health Organization. Cervical cancer overview [Internet]. Available from: https://www.who.int/southeastasia/activ ities/cervical-cancer

8. Small W, Bacon MA, Bajaj A, Chuang LT, Fisher B, Harkenrider M, et al. Cervical cancer: a global health crisis. Cancer. 2017;123(13):2404-12. Doi: 10.1002/cncr.306672017;

9. Claritha DC, Dewi C, Christina S. Hubungan antara lesi prakanker serviks dengan sosiodemografi perempuan di Kecamatan Legok Kabupaten Tangerang Tahun 2018. J Muara Sains, Teknol Kedokt dan Ilmu Kesehat. 2020;4(1):193.

10. Balasubramaniam SD, Balakrishnan V, Oon CE, Kaur G. Key molecular events in cervical cancer development. Medicina. 2019;55(7):384.

11. Pruski D, Millert-Kalinska S, Lewek A, Kedzia W. Sensitivity and specificity of HR HPV E6/E7 mRNA test in detecting cervical squamous intraepithelial lesion and cervical cancer. Ginekol Pol. 2019; 90(2):66-71.

12. Stiasny A, Kuhn C, Mayr D, Alexiou C, Janko $\mathrm{C}$, Wiest I, et al. Immunohistochemical evaluation of E6/E7 HPV oncoproteins staining in cervical cancer. Anticancer Res. 2016;36(6):3195-8.

13. Savira M. Biologi molekuler human papilloma virus. J Ilmu Kedokt. 2018;11(1):1.

14. Permana PH, Sulaini P, Hilbertina N. Karakteristik karsinoma serviks di RS Dr . M . Djamil Padang. Kesehat Andalas. 2017;6(2):357-63.

15. Herlana F, Nur IM, Purbaningsih W. Karakteristik pasien kanker serviks berdasar atas usia, paritas, dan gambaran histopatologi di RSUD Al-Ihsan Bandung. Bandung Meet Glob Med Heal. 2017; 1(22):138-42.

16. Rozario S do, Silva IF da, Koifman RJ, Silva IF da. Characterization of women with cervical cancer assisted at Inca by 
histological type. Rev Saude Publica. 2019;53:88.

17. Oktaviani BD, Sriwidyani NP, Sumadi IWJ. Karakteristik klinikopatologi penderita kanker serviks uteri berdasarkan data di Laboratorium Patologi Anatomi RSUP Sanglah Denpasar Tahun 2011-2015. EJurnal Med [Internet]. 2018;7(8):1-6. Available from: http:/ojs.unud.ac.index/ index.php/eum

18. Nowakowski A, Cybulski M, Buda I, Janosz I, Olszak-Wxąsik K, Bodzek P, et al. Cervical cancer histology, staging and survival before and after implementation of organised cervical screening programme in Poland. PLoS One. 2016;11(5):1-10.

19. Latifah SRN. Hubungan stadium klinis dengan derajat diferensiasi sel pada pasien karsinoma sel skuamosa serviks uteri di RSUD Abdul Moeloek Bandar Lampung. Ilmu Kedokt dan Kesehat. 2017; 4:1-8

20. Romli R, Shahabudin S, Saddki N, Mokhtar N. Cervical cancer and Pap smear screening: knowledge, attitude and practice among working women in northern state of Malaysia. Med J Malaysia. 2019;74(1):8-14.

21. Juanda D, Kesuma H. Pemeriksaan metode IVA (Inspeksi Visual Asam Asetat) untuk pencegahan kanker serviks. J Kedokt dan Kesehat [Internet]. 2015;2(2):169-74. Available from: https://www.mendeley.com/catalogue/3 cdb68d5-93db-331f-8896-

627 a17889398/?utm_source=desktop\& utm_medium $=1.19 .4 \& u t m \_c a m p a i g n=$ open_catalog\&userDocumentId=\%7B5 2ac24c9-f483-4090-8cdcb9f4d61c7aa9\%7D

22. Domgue JF, Cunningham SA, Yu RK, Shete S. Prevalence and determinants of cervical cancer screening with a combination of cytology and human papillomavirus testing. Ann Epidemiol. 2019;36(2019):40-7.

23. Mittal S, Basu P, Lucas E. Atlas of visual inspection of the cervix with acetic acid for screening, triage, and assessment for treatment: IARC CancerBase No. 16. 2020; Available from: https://screening. iarc.fr/atlasvia.php

24. Vahedpoor Z, Behrashi M, Khamehchian T, Abedzadeh-Kalahroudi M, Moravveji
A, Mohmadi-Kartalayi M. Comparison of the diagnostic value of the visual inspection with acetic acid (VIA)and Pap smear in cervical cancer screening. Taiwan J Obstet Gynecol [Internet]. 2019;58(3):345-8. Available from: https://doi.org/10.1016/j.tjog.2019.03.0 10

25. Indarti J, Pratama YS. The accuration of liquid based cytology and HPV DNA test combination as precervical cancer lesion screening. Indones J Obstet Gynecol. 2017;5(4):241.

26. Shrivastava SK, Lewis S, Sastri SC, Lavanya G, Mahantshetty U, Engineer R. Cancer cervix: Establishing an evidence-based strategy, an experience of a tertiary care centre in India. Curr Probl Cancer [Internet]. 2018;42(2):137-47. Available from: http://dx.doi.org/10.1016 /j.currproblcancer.2018.01.005

27. Bhattacharyya AK, Nath JD, Deka H. Comparative study between pap smear and visual inspection with acetic acid (via) in screening of CIN and early cervical cancer. J Midlife Health. 2015; 6(2):53.

28. Huy NVQ, Tam LM, Tram NVQ, Thuan DC, Vinh TQ, Thanh CN, et al. The value of visual inspection with acetic acid and Pap smear in cervical cancer screening program in low resource settings - A population-based study. Gynecol Oncol Reports [Internet]. 2018;24(February): 18-20. Available from: https://doi.org/ 10.1016/j.gore.2018.02.004

29. Mastutik G, Alia R, Rahniayu A, Kurniasari N, Rahaju AS, Mustokoweni S. Skrining kanker serviks dengan pemeriksaan Pap Smear di Puskesmas Tanah Kali Kedinding Surabaya dan Rumah Sakit Mawadah Mojokerto. Maj Obstet dan Ginekol. 2015;23(2):54-60.

30. Rad FS, Ghaebi M, Zarabadipour S, Bajelan A, Pashazade F, Kalhor M, et al. Comparison of diagnostic methods in detection of squamous cell abnormalities in Iranian women with abnormal pap's smear test and associated demographic and issues. Iran J Pathol. 2020; 15(2):106-16.

31. Hapsari Y, Hidajat D, Setyorini RH, Hartati F. Prevalensi dan faktor risiko highrisk HPV pada inspeksi visual asam asetat positif di Mataram NTB. Unram Med J. 
60 Medical Scope Journal (MSJ), Volume 3, Nomor 1, Juli-Desember 2021, hlm. 47-60

2019;8(2):12.

32. Kummar V, Abbas A, Aster J. Buku Ajar Patologi Dasar Robbins (10th ed). Indon. Ham MF, Saraswati M, editors. Singapore: Elsevier, 2020.

33. World Health Organization. Training of Health Staff in VIA, HPV Detection Test And Cryotherapy - Trainee's Handbook. New Delhi: World Health Organization, Regional Office for South-East Asia, 2017; p. 39-40.

34. Kurman RJ, Carcangiu ML, Herrington CS, Young RH. WHO classification of tumours of female reproductive organs. Int Agency Res Cancer. 2014;20(3): 170-206.

35. Nuci M, Oliva E. Gynecologic Pathology (Foundations in Diagnostic Pathology) (1st ed). Goldblum J, editor. Edinburgh: Elsevier Churchill Livingstone, 2009.

36. American Cancer Society. HPV and HPV testing. Am Cancer Soc [Internet]. 2020; Available from: https://www.cancer. org/cancer/cancer-causes/infectiousagents/hpv/hpv-and-hpv-testing.html 